\title{
Handmade cloning: recent advances, potential and pitfalls
}

\author{
Geetika Verma ${ }^{\dagger}$, JS Arora ${ }^{*}$, RS Sethi, CS Mukhopadhyay and Ramneek Verma
}

\begin{abstract}
Handmade cloning (HMC) is the most awaited, simple and micromanipulator-free version of somatic cell nuclear transfer (SCNT). The requirement of expensive micromanipulators and skilled expertise is eliminated in this technique, proving it as a major revolution in the field of embryology. During the past years, many modifications have been incorporated in this technique to boost its efficiency. This alternative approach to micromanipulator based traditional cloning (TC) works wonder in generating comparable or even higher birth rates in addition to declining costs drastically and enabling cryopreservation. This technique is not only applicable to intraspecies nuclear transfer but also to interspecies nuclear transfer (iSCNT) thus permitting conservation of endangered species. It also offers unique possibilities for automation of SCNT which aims at production of transgenic animals that can cure certain human diseases by producing therapeutics hence, providing a healthier future for the wellbeing of humans. The present review aims at highlighting certain aspects of HMC including recent advancements in procedure and factors involved in elevating its efficiency besides covering the potentials and pitfalls of this technique.
\end{abstract}

Keywords: Handmade cloning, Micromanipulator, Somatic cell nuclear transfer, Transgenic, Zona free cloning

\section{Introduction}

The birth of Dolly in 1997 [1] by the somatic cell nuclear transfer (SCNT) technique was a major scientific innovation in animal cloning. After this, animal cloning by SCNT gained momentum and animal clones from various species were generated (Table 1). Traditional cloning (TC) necessitate the use of expensive micromanipulators for enucleation of recipient oocytes, followed by insertion of a donor somatic cell or nucleus into enucleated oocyte by fusion [2] or direct injection [3] besides requiring skilled expertise. One of the major necessities in TC was to reduce the costs without compromising with the efficiency. Keeping this in view, some adaptations were made in TC to make it more robust and inexpensive, which ultimately led to the birth of handmade cloning (HMC), a technique also known as zona free cloning or hand guided technique [4]. Based on SCNT, HMC is advanced procedure of enucleation of zona-free mammalian oocytes by handbisection using a metal blade [5-7] or by employing

\footnotetext{
* Correspondence: drarora2003@gmail.com

${ }^{\dagger}$ Equal contributors

School of Animal Biotechnology, Post Graduate Institute of Veterinary

Education and Research, Guru Angad Dev Veterinary and Animal Sciences

University, Ludhiana 141004 Punjab, India
}

density gradient centrifugation [8] or by chemicals [9]. The first known zona-free nuclear transfer approach was performed by Tatham et al. [8] but it failed to generate calves. Later on, Vajta et al. [5] developed the improved HMC technique utilizing sharp blades for bisection of zona-free oocytes under steriomicroscope.

In addition to intraspecies nuclear transfer, HMC has also been exploited for interspecies somatic nuclear transfer (iSCNT). Due to oocyte availability constraints in case of endangered animals, iSCNT is a viable option offering embryo reconstruction by fusing donor cells from the species which needs to be cloned or protected from extinction with recipient oocytes of different animal species. Although some wild animals have been cloned by this method, yet it is less efficient when compared with intraspecies nuclear transfer [10]. It is important to mention that any animal created using either form of SCNT i.e. TC or HMC is not a true clone of its donor because only nuclear DNA of the clone is same to that of donor but not mitochondrial DNA. So, for a clone to be true to its donor, it must inherit nuclear as well as mitochondrial DNA. The present review highlights all the possible recent adaptations incorporated to improve the efficiency of $\mathrm{HMC}$ in bovines, caprines and 
Table 1 List of animals successfully cloned by either forms of SCNT i.e. TC and HMC

\begin{tabular}{llll}
\hline S.No. & Animal & Reference(s) & \\
\cline { 4 - 4 } & & Traditional cloning $(\mathrm{TC})$ & Handmade cloning $(\mathrm{HMC})$ \\
\hline 1. & Cattle & {$[78,79]$} & {$[38,50,80,81]$} \\
2. & Buffalo & {$[82]$} & {$[83]$} \\
3. & Goat & {$[84-87]$} & - \\
4. & Sheep & {$[1]$} & {$[73]$} \\
5. & Pig & {$[88]$} & {$[69,89,90]$} \\
6. & Horse & {$[91]$} & {$[92]$} \\
7. & Mice & {$[3]$} & - \\
8. & Cat & {$[93]$} & - \\
9. & Rabbit & {$[94]$} & - \\
10. & Rat & {$[95]$} & - \\
11. & Dog & {$[96]$} & - \\
12. & Ferret & {$[97]$} & - \\
13. & Wolf & {$[98]$} & - \\
14. & Mule & {$[99]$} & - \\
15. & Camel & {$[100]$} & - \\
\hline
\end{tabular}

porcines. All the possible mechanisms of performing $\mathrm{HMC}$, in addition to its potential and limitations have been addressed besides, discussing future prospects of this technique.

\section{Step by step guide to HMC}

Both TC and HMC aim at same objective but vary predominantly in their requirements for instrumentation. Table 2 summarizes the similarities and differences between HMC and TC. HMC can be broadly divided into two parts: first dealing with the preparation of donor

Table 2 Summary of similarities and differences between HMC and $\mathrm{TC}$

\begin{tabular}{llll}
\hline S.No. & Features & TC & HMC \\
\hline 1. & Somatic cell nuclear transfer & $\checkmark$ & $\checkmark$ \\
2. & Synchronization of donor cell & $\checkmark$ & $\checkmark$ \\
3. & High no. of attempts & $\checkmark$ & $\checkmark$ \\
4. $\quad \begin{array}{l}\text { Problems associated with nuclear } \\
\text { reprogramming and reproducibility }\end{array}$ & $\checkmark$ & $\checkmark$ \\
& $\begin{array}{l}\text { of experiments } \\
\text { 5. }\end{array}$ & $\times$ & $\times$ \\
6. $\quad$ Mrue clone & Micromanipulator-free & $\times$ & $\checkmark$ \\
7. & Zona- free & $\times$ & $\checkmark$ \\
8. $\quad$ Problems associated with zona & $\times$ & $\checkmark$ \\
9. & Nullucida removal & & \\
10. $\quad$ Costs & Lower & Higher \\
\hline
\end{tabular}

somatic cell or nuclei and the second dealing with preparation of enucleated oocytes, which is to be fused with donor nuclei later on.

\section{Preparation of donor somatic cell or nuclei Source of donor nuclei}

HMC was initially established for bovine nuclear transfer using embryonic cells as source of donor nuclei [11]. However, with continuous experimentation in this field many other sources have been explored. Various sources are listed in Table 3. Although any somatic cell can be use as a donor for HMC, yet choice of donor cells is very essential to overcome the problems related to nuclear reprogramming. Saini et al. [12] has observed that donor cells of fibroblast origin are easier to reprogram than those of epithelial origin in iSCNT through HMC. Primary cell cultures are established aseptically following standard procedures depending upon the source.

\section{Synchronization between donor nucleus and the recipient cytoplasm}

The synchrony between the cell cycle of donor nucleus and the recipient cytoplasm is considered to be one of the key factors needed to increase nuclear reprogramming capacity and, thereby, cloning efficiency [13]. The use of quiescent donor cells in the G0 or arrested in the G1 phases of the cell cycle has become a rule in cloning [14], since such cell cycle phases are considered as more suitable for proper reprogramming [13, 15-18]. In addition, the use of donor cells at other cell cycle phases usually leads to poor embryo development after cloning due to either chromosome pulverization induced by premature chromosome condensation when occurring in $\mathrm{S}$ phase, or aneuploidy in G2/M phases [13].

Table 3 List of sources of donor nuclei for HMC

\begin{tabular}{llll}
\hline S.No. & Source of donor nuclei & Species & Reference(s) \\
\hline 1. & Pronuclear stage embryos & Mouse & {$[101,102]$} \\
2. & Embryonic blastomeres & Mouse & {$[65]$} \\
3. & Cumulus cells & Cow & {$[4,5]$} \\
4. & Embryonic stem cells (ESC) & Buffalo & {$[60]$} \\
5. & Adult fibroblast cells & Buffalo & {$[52]$} \\
& & Cow & {$[47,58,103]$} \\
& & Goat & {$[10,12,54]$} \\
& & Sheep & {$[73]$} \\
6. & Natural killer T cells & Mice & {$[104]$} \\
7. & Fetal fibroblasts & Goat & {$[55,85,105]$} \\
& & Water buffalo & {$[106]$} \\
& & Pig & {$[69]$} \\
8. & Adipose tissue derived-Mesenchymal & Goat & {$[107]$}
\end{tabular}


The different procedures for the cell cycle synchronization of donor cells in G0/G1 phase includes use of serum starvation, contact inhibition by cell confluence, and use of chemicals like cycloheximide, DMSO, and roscovitine. Among all the different procedures, cell confluence by contact inhibition appears to be one of the most widely used methods nowadays $[19,20]$ as the proportion of cells in G0/G1 appeared to be higher by cell confluence than any other protocol. Moreover, serum starvation or the use of chemical agents for cell cycle synchronization prior to somatic cell cloning not only impose a potential stressful condition on cells, but also do not appear to promote any improvement in embryo development [21].

\section{Preparation of recipient enucleated oocytes/cytoplasts Source of oocytes}

Oocytes can be retrieved either from live animal (in vivo) or slaughtered animal (abattoir). Oocytes have been obtained in vivo from hormonally stimulated females by laparoscopic oocyte recovery (LOR) or transvaginal oocyte retrieval (TVOR), also known as Ovum pick up (OPU) or from slaughterhouse ovaries from nonstimulated females by post-mortem [22]. Although oocytes in large numbers are available in case of slaughtered animal yet it suffers from a limitation of absence of information about pedigree of dam which is available in case of OPU.

\section{In vitro maturation (IVM) of oocytes}

Mammalian oocytes are arrested at the diplotene stage of the first meiotic division. In response to the preovulatory surge of gonadotrophins some of the oocytes undergo resumption of meiosis characterized by germinal vesicle breakdown, chromosome condensation, formation of the first meiotic spindle, expulsion of the first polar body and arrest in metaphase of the second meiotic division. These events are defined as oocyte maturation and lead to an ovulated fertilizable oocyte. For IVM, oocytes are incubated for upto 24 h (bovines) [23, 24]; $27 \mathrm{~h}$ (caprines) [22, 25] and $44 \mathrm{~h}$ (porcines) [26] in medium supplemented with hormones (gonadotropins) and growth factors under mineral oil at $39{ }^{\circ} \mathrm{C}$ in $5 \% \mathrm{CO}_{2}$ in humidified air. Gonadotrophins play a major role in triggering resumption of meiosis in the oocyte and expansion of cumulus oophorus.

\section{Zona pellucida removal}

After IVM, matured oocytes are selected on basis of cumulus expansion or Giemsa staining. Cumulus-oocyte complexes (COCs) are denuded by pipetting or vortexing [27]. Denuded oocytes are subjected to $0.5 \%$ protease for zona pellucida removal. Zona pellucida can also be removed by pronase treatment [28] or hyaluronidase treatment [4].

\section{Enucleation of zona- free oocyte and Cytoplast selection}

Zona-free oocytes can be enucleated by chemicals, density gradient centrifugation or by hand using a sharp blade. A non-invasive chemical enucleation procedure was first described by Fulka and Moor [9] for mouse oocytes in which chemical treatment blocks DNA topoisomerase II during metaphase-I thus, inhibiting the oocyte chromosomes separation and expelling the whole chromatin into the first polar body, resulting in a chromatin-free cytoplast, also known as chemically enucleated oocyte (CEO) [29].

A brief treatment of bovine [30]; porcine [31] and caprine [32] oocytes with demecolcine (DEM) produces a membrane protrusion that contains a mass of condensed chromosomes, which can be removed easily. Other chemicals such as nocodazole, etoposide, caffeine, and MG132, have been used to induce or assist oocyte enucleation [31]. Tatham et al. [8] utilized density-gradient centrifugation for enucleation of zona-free oocytes. Vajta et al. [5] developed superior HMC technique employing sharp blades for bisection of zona-free oocytes by hand, hence the name HMC. After removal of zona pellucida, a cone protrudes out of the zona-free oocyte referred as protrusion cone or oocyte rod. Protrusion cone oriented bisection is done using an embryo-splitting blade under a stereomicroscope to obtain zona-free cytoplasts. The protrusion cone or oocyte rods should be bisected near the end of the rod as it is the place where the polar body is located [29]. If the polar body is lost or unable to locate or the egg is a zygote it is better to dissect the egg into two equal halves to generate cytoplasts [33]. After bisection, all halved-oocytes without chromatin, known as cytoplasts or hemi-cytoplasts, are selected by screening for nuclear material stained with Hoechst 33342 under ultraviolet (UV) light. However, use of UV may prove detrimental to oocytes. Moreover, lipid droplets in the ooplasm obstruct identification and enucleation of metaphase II (MII) chromosomes, especially in bovine species, ultimately affecting the efficiency of the process. To overcome this problem, a new experimental system have been employed, which is based on fluorescent observation of chromosomes in living oocytes without any damage by injecting fluorescence-labeled antibody conjugates that bind to chromosomes and fluorescent observation using a conventional halogen-lamp microscope [34].

\section{Embryo reconstruction and activation}

Reconstruction and nuclear transfer is achieved by quickly exposing one or two enucleated hemi-cytoplasts to phytohemoagglutinin (PHA). PHA helps in attachment of donor cell with cytoplasts by gluing the surface of cytoplast and makes it sticky to easily get attached to the surface of donor cell, leading to formation of a couplet. The couplet may achieve approximately either 50 or 
$100 \%$ of the final cytoplasmic volume, depending upon one cytoplast or two cytoplasts fusion respectively. After attachment, reconstructed hemi-embryos (50\% volume) or embryos (100\% volume) are fused either by single step electrofusion or two step electrofusion. A single low-voltage AC pulse in electrofusion medium is given in a chamber coupled to an electrofusion apparatus. Vajta et al. [28] make use of two electric fusions as shown in Fig. 1. The cytoplast is dropped over a single somatic cell or karyoplast and exposed to electric pulse. The pair (demi-clone embryo) is removed and then subjected to second electrical fusion involving a demi-clone embryo and second half cytoplast. This technique requires more number of oocytes as a source of recipient cytoplasts than a single step electrofusion. Electrofusion is followed by chemical activation of reconstructed clone embryos in ionomycin and N-6 dimethylaminopurine (6-DMAP) [21]. Ionomycin induces calcium release which suppresses maturation promoting factor (MPF) and 6-DMAP is a protein kinase inhibitor that prevents reformation of MPF, hence resulting in release from metaphase.

\section{In vitro culture (IVC)}

Cloned embryos are then cultured in vitro individually in microwells using the well-of-the-well (WOW) system. WOW culture system provides three dimensional blastomere arrangements in zona-free embryos [35]. Activated cloned embryos $(1 \times 100 \%)$ or two cloned hemi- embryos $(2 \times 150 \%$, embryo aggregation $)$ are placed in each microwell (WOW). All structures are cultured in vitro to the blastocyst stage. Cleavage rate is assessed $48 \mathrm{~h}$ after activation [21]. It has been observed by Kaith et al. [36] that embryos which cleave early have higher developmental competence and quality than those that cleave relatively later.

\section{Assessment of embryo quality, stage of development and cell density}

Embryo quality and stage of development are assessed by morphology according to the guidelines from the International Embryo Transfer Society (IETS). In the case of zona-free embryos, especially for expanded and hatched blastocysts, stages of development are assessed by comparing embryo size and morphology with blastocysts from the zona-intact control groups. This is done by exposing blastocysts to Hoechst 33342 under UV light in an epifluorescent microscope.

\section{Embryo transfer}

After assessment of embryo's quality and stage, it is subjected to transfer into recipient animal. Embryos are transferred on day seven for cattle, goat, pig and day eight for buffalo to synchronised recipient donors.

\section{Embryo vitrification and in-straw thawing}

Based on assessment of embryo quality, stage of development and cell density, the embryos of good quality

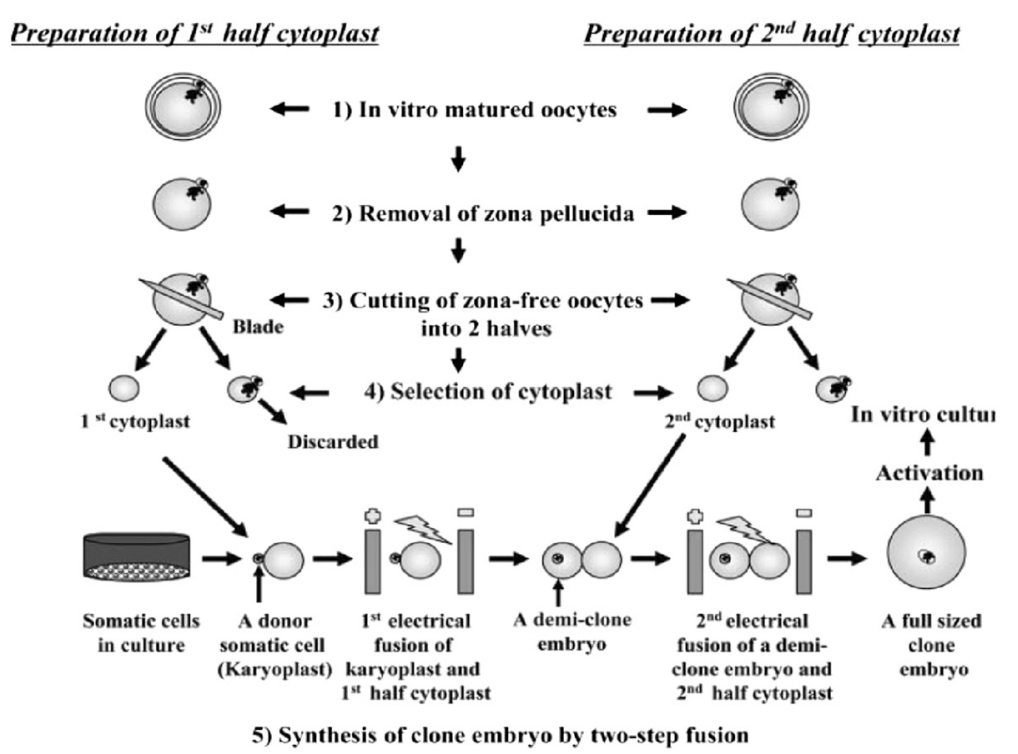

Fig. 1 Outline showing procedures for Handmade cloning (HMC) (Reprinted from Nagai et al. [33]). Figure shows (1) the preparation of cytoplast by removal of cumulus layer of in-vitro matured oocytes (2) removal of zona pellucida from oocyte by digestion with pronase (3) hand bisection of zona-free oocytes with a blade, hence the name hand-made cloning, to obtain cytoplast (4) selecting a cytoplast under stereomicroscope (5) reconstructing embryo by fusing a donor somatic cell with cytoplast generating a demi-clone embryo which is again fused with 2nd half cytoplast (generated by same procedure as 1st cytoplast) to obtain a full sized clone embryo that is activated and implanted at blastocyst stage into recipient animal 
can be cryopreserved for long time in liquid nitrogen. Blastocysts are vitrified using the open-pulled straw (OPS) method as described by Vajta et al. [37], which resulted in healthy offspring after transfer [38]. Considering the delicacy of zona-free embryos, modification of the vitrification procedure may be required to achieve the commercially viable level of efficiency [27]. Embryos are thawed using the in-straw dilution method prior to embryo transfer $[39,40]$.

\section{Factors contributing to high efficiency of HMC in vitro}

\section{Effect of method adopted for enucleation of oocyte}

Chemically assisted enucleation has been observed as more efficient and reliable method for goat HMC as compared to oriented bisection of oocyte by hand [41]. DEM treatment disrupts spindle microtubules, induces chromosome condensation and has significantly greater potential than that of embryos generated from mechanically enucleated oocytes in vivo [31]. The rates of enucleation, cell fusion and blastula formation of goat oocytes has been found to be similar among caffeineand DEM-assisted enucleation and significantly higher than mechanical enucleation as reported by Wang et al. [42]. DEM-assisted enucleation is advantageous over mechanical enucleation as it decreases the cytoplasmic volume of the oocyte minimally without reducing the level of MPF. High MPF activity might promote cytoplasmic maturation and improve the developmental competence of oocytes [31]. Moreover, enucleation with chemicals like DEM obviates the need of inverted fluorescence microscope and destructive chromatin staining and UV irradiation for cytoplast selection. However, contrary to it, oriented bisection by hand has been found more promising than chemical assisted enucleation in case of fibroblast derived transgenic porcine embryos [43]. Similarly, the production of bovine blastocysts using oocytes enucleated by DEM showed lower embryonic developmental rates than those obtained with mechanically enucleated oocytes [44]. DEM treatment has negative effect on the completion of second polar body extrusion, which results in a significant number of partially enucleated oocytes in which the chromosomes eventually reintegrate into the cytoplasm [44, 45]. However, the shorter treatments with DEM or the use of alternative microtubule disrupting drugs may solve these problems. These alternative drugs must be chosen carefully to minimize their detrimental effects on the developmental potential of the cytoplasts [46].

\section{Effect of final cytoplasmic volume of fused hemicytoplasts}

The effect of the fusion of hemicytoplasts or aggregation of hemiembryos, varying the final cytoplasmic volume, on development and cell density of embryos produced by HMC has been evaluated by Ribeiro et al. [47]. The increase in cytoplasmic volume, either by fusion or by aggregation, had a positive effect on embryo development, supporting the establishment of pregnancies and the birth of a viable clone calf after transfer to recipients. It has been shown that the increase in the number of aggregated structures within each WOW follows a linear increase in cleavage, blastocyst rate, and cell density. The quality of handmade cloned porcine embryos has been improved by multiple embryo aggregations [48]. However, hemi-cytoplasts with cytoplasmic volume ( $85 \%$ vs. $2 \times 50 \%)$ showed no effect on fusion rates after embryo reconstruction, rendering it advantageous for species such as the goat, for which oocyte supply and numbers are usually limiting factors [22].

\section{Effect of zona pellucida removal}

As only small, round and intact cells, with visibly soft membranes, are used for embryo reconstruction [49] so zona pellucida removal is an important parameter and it has been found that pronase digestion in the presence of serum is an efficient and harmless method for removal of zona pellucida, even when large quantities of oocytes (up to 150) are digested together [4]. Moreover, fluidity of zona-free eggs should be maintained in order to prevent egg lyses. Elsheikh [29] observed that on culturing zona-free eggs in media supplemented with Cytochalasin $\mathrm{B}$, their cytoplasm generally becomes more fluid and thus deforming them into cylindrical rods. In addition, suction of eggs into the deforming pipette should be done carefully, slowly and very smoothly to avoid egg lyses. The end of this pipette should be well fire-polished to avoid injury of the zona-free eggs. However, Oback et al. [50] found no significant difference in development to live calves between zona-free and zona-intact embryos derived from the same adult fibroblast line. Blastocysts of transferable quality were obtained at similar rates from zona-free and control zona-intact embryos.

\section{Effect of cytoplast and donor somatic cell fusion}

It has been observed by Vajta et al. [4] that in electrofusion, the cytoplast-somatic cell fusion pairs should be placed between the wires of the fusion chamber for significantly higher rates of fusion than in a random position or with somatic cells furthest from the wire. Also, the second fusion is successful regardless of the time between the first and second fusion. But, if the second fusion pulse occurs before completion of the first fusion, the first fusion could be disturbed, even if the second fusion has completed successfully. Elsheikh [29] observed that during aggregation of cytoplasts and donor nuclei the area of contact between them should be wide to achieve high fusion rates. 
Effect of different culture media and culture systems

The cloned embryo culture medium has always been very important. In the zona-free method the frequent change of medium during culture, is not preferred [51]. Cleavage and blastocyst rates for zona-free cloned buffalo are higher in Research Vitro Cleave (RVCL; Cook $^{\oplus}$, Australia) medium compared to modified Charles Rosenkrans 2 (mCR2) and modified Synthetic Oviductal Fluid (mSOF) medium as observed by Shah et al. [52]. Selokar et al. [53] performed interspecies handmade cloned embryo production, by nuclear transfer of cattle, goat and rat fibroblasts to buffalo oocytes, using RVCL as the culture medium. Dutta et al. [54] used RVCL media to produce zona-free cloned goat embryos. North Carolina State University (NCSU) medium has been used for porcine embryos [26, 31]. Studies on zona-free cloned buffalo [52] and goat embryos [55] revealed that flat surfaces (FS) used as culture system yielded significantly higher blastocyst rates than WOW or microdrops (MD). Also, development in WOW has found to be significantly better than MD. Vajta et al. [4] studied the effect of two common constituents of the bisection medium used for embryo manipulation: sucrose, an osmotic buffer, and cytochalasin B, a cytoskeleton relaxant. Sucrose incubation has found to decrease the percentage of demioocytes surviving bisection with an intact cell membrane whereas Cytochalasin B increases the survival.

\section{Other factors enhancing the blastocyst/oocyte rates}

Blastocyst/oocyte rates can be enhanced by prolonged incubation between reconstruction, application of serumcontaining medium for $\mathrm{Ca}$-ionophore incubation, and individual incubation of reconstructed zona-free embryos in DMAP. These changes decrease lysis rates and prevent unintended attachment of embryos to each other [4]. Zonafree embryos are more sensitive to chemical activation [6] so, a low concentration $(2 \mathrm{mmol} / \mathrm{L})$ of $\mathrm{Ca}$-ionophore can be employed. The incubation period between reconstruction and activation and during DMAP exposition should be prolonged from 3 to $4 \mathrm{~h}$ and from 4 to $6 \mathrm{~h}$, respectively, according to the observations of Alberio et al. [56], Kasinathan et al. [57] and Beyhan et al. [58].

Supplementation of calf serum (CS) in culture medium for in vitro fertilised embryos has been found to significantly increase the blastocyst/oocyte rate as compared to bovine serum albumin (BSA) as observed by Vajta et al. [4]. Reprogramming of donor cells by pre-treating them with oocyte extracts and selection of developmentally competent oocytes through brilliant cresyl blue (BCB) staining for recipient cytoplast preparations may enhance expression of developmentally important genes in hand-made cloned embryos at levels similar to in vitro fertilized counterparts [59]. Similar findings have been demonstrated by Mohapatra et al. [60], RodríguezGonzález et al. [61] and Roca et al. [62] for selecting buffalo, prepubertal goat and pig oocytes respectively using $\mathrm{BCB}$ staining.

\section{Problems limiting the success of HMC}

The problems that limit the success of HMC are mainly associated with automation of the technique and with use of zona-free embryos. These are discussed in detail here.

\section{Problem associated with automation of the technique}

The automation of HMC procedure can make cloning easier, simpler and time-saving technique and it can be achieved by use of microchannels. Efforts have been made by Vajta et al. [63] using microchannels. However, there is still lack of integration of the individual steps into a production line and unfortunately, attempts in this field are meagre which present a main hurdle in the advancement of this field [64]. Efforts are needed to overcome the existing fundamental drawbacks like the occurrence of gas bubbles in the channels during incubation, hampering the passage of solutions and deformation of the embryos. Hence, an advanced technical setting to control, fine-tune and integrate processes is required.

\section{Problems of zona-free embryos}

Normal embryos are equipped with zona-pellucida which protects them not only from toxic substances in culture media [65] but it is essential for even undisturbed embryonic development $[65,66]$ besides preventing separation of blastomeres in cleaving embryos. Difficulty in obtaining newborns from zona-free embryos has been reported [67]. The rates at which zona-free blastomeres separated at the 2-cell stage developed to the blastocyst stage and to full term were lower than those of zona-intact 2-cell embryos [68]. Further, the cell number of inner cell mass (ICM) in blastocysts derived from zona-free 4-cell embryos has been found lower resulting in low rates of implantation [66] which can be overcome by using WOW technique that provides three dimensional blastomere arrangement in zona-free embryos [35]. The zona-free embryos might be affected by toxic substances in culture media. Furthermore, their development might be disturbed. These problems can be overcome by using an artificial zona pellucida [65].

\section{Benefits of HMC}

\section{High efficiency and productivity}

HMC is highly efficient or even superior to TC. Studies to produce transgenic pigs that express the functional nematode fat- 1 gene have been conducted by Zhang et al. [69]. After 7 days of culture in vitro, $37 \%$ of 
reconstructed embryos developed to the blastocyst stage by HMC and a total of 14 live offspring were produced, which is more efficient than TC. Using HMC, about 100-140 reconstructed embryos can be generated by just two qualified technicians in 2.5-3 h [70]. Having this large number of embryos correlates to higher probability of efficient transfer and high productivity.

\section{Reduced labour and costs}

In contrast to the complicated tools, like micromanipulators and microscopes which are required for TC, only one stereomicroscope and one electrofusion machine are required for HMC, making it simple and cost-effective technique. For reconstruction of embryos, two step fusion can be reduced to one step which reduces requirement of more oocytes and hence, reduces labour [21].

\section{Time saving}

Fortunately, HMC embryos can be cryopreserved successfully with vitrification. Initial reports suggest no decline in pregnancy rates after cryopreservation [64]. Pregnancy rates of around $50 \%$ can be achieved with cloned zona-free embryos in cattle [71]. As per the existing data, no significant difference in the rate of developmental anomalies between TC and HMC was observed in cattle. Moreover, in TC single oocyte can be processed at a time while in HMC multiple oocytes can be processed, hence saving time.

\section{Future perspectives}

HMC holds a promising future. In the future improved HMC programs could be developed for the production of cloned animals with desired traits, rescue of endangered animal species and create transgenic animals for medical purposes like xenotransplantation.

\section{Conservation of endangered species}

HMC allows both interspecies and intraspecies nuclear transfer. Being more efficient and time saving than TC, efforts can be made in exploiting HMC to generate large number of interspecies embryos for conserving endangered species. Studies has shown that not only, the interspecies embryos of goat can be produced using sheep oocytes as donor cytoplast but also the percentages can be improved by using RVCL media for culturing of the embryos as illustrated by Khan et al. [10]. Wild buffalo embryos by iSCNT through HMC using somatic cells of wild buffalo and oocytes of domestic buffalo have been generated [11, 72]. However, more studies in this area are required to optimize media, culture conditions and validation of embryo development for iSCNT by HMC.

\section{Production of transgenic animals}

Transgenic animals, expressing a gene of interest, can be generated by this technique which will surely boost up the field of therapeutics and medicine, besides, contributing organs for xenotransplantation. HMC has been exploited to produce transgenic sheep with elevated levels of omega-3 fatty acids [73] and transgenic pigs expressing the functional nematode fat- 1 gene [69]. However, using HMC, little work has been done in this context. For therapeutic purposes, patientspecific embryonic stem cells are required i.e. the cells must be genetically identical to patient, which is a problem of reconstructed embryos, that need to be addressed in this field.

\section{Automation of HMC}

The utmost benefit of HMC is large scale production. Microchannel or microfluidics technology can help in this. Almost all the steps required for HMC can be performed in microchannels [74]. Contrary to it, automation seems to be impossible in TC. This would lead to a revolution for SCNT and all embryo technologies, ensuring production of high grade embryos.

\section{Nuclear reprogramming studies}

Although HMC and TC have been used for cloning many animal species yet both are surrounded with certain limitations including cloning syndrome (developmental abnormalities), poor embryo survival rate, lack of understanding of the mechanism(s) of reprogramming of the transferred somatic cell nucleus [33], placental abnormalities, pregnancy losses and reproducibility of the experiments [75-77]. Detailed studies of underlying mechanisms of reprogramming need to be done in order to overcome above hindrances.

\section{Conclusions}

HMC has emerged as simplified alternative to traditional cloning. It is as efficient as or even higher than micromanipulator-based SCNT in animals. This technique is devoid of micromanipulators and has shown promising prospects of low cost production of genetically modified animals. A little more efforts in this field are required to dissipate this technology in every sector of livestock for all species.

\footnotetext{
Abbreviations

SCNT: Somatic cell nuclear transfer; HMC: Handmade cloning; TC: Traditional cloning; iSCNT: Interspecies nuclear transfer; FS: Flat surface; WOW: Well of the Wells; MD: Microdrops; RVCL: Research Vitro Cleave; mCR2: Modified Charles Rosenkrans 2; mSOF: Modified Synthetic Oviductal Fluid; LOR: Laparoscopic oocyte recovery; TVOR: Transvaginal oocyte retrieval; OPU: Ovum pick up; CS: Calf serum; BSA: Bovine serum albumin; BCB: Brilliant cresyl blue; ICM: Inner cell mass; 6-DMAP: N-6 dimethylaminopurine; IETS: International Embryo Transfer Society; ESC: Embryonic stem cells; COCs: Cumulus-oocyte complexes; OPS: Open-pulled straw; PHA: Phytohemoagglutinin; CEO: Chemically enucleated oocyte;
} 
UV: Ultraviolet; MPF: Maturation promoting factor; IVM: In vitro maturation; MII: Metaphase II; IVC: In vitro culture; DEM: Demecolcine; NCSU: North Carolina State University.

\section{Competing interests}

The authors declare that they have no competing interests.

\section{Authors' contributions}

GV made substantial contributions to conception, design and writing of this review. JSA contributed in editing and revising the review critically for important intellectual content. RSS and CSM ensured accuracy of this review. RV gave final approval of the version to be published. All authors read and approved the final manuscript.

\section{Acknowledgements}

The authors would like to acknowledge Dr. S. K. Singla (Principal Scientist) and Dr. M. S. Chauhan (Principal Scientist) at Embryo Biotechnology Lab, Animal Biotechnology Centre, National Dairy Research Institute, Karnal (Haryana), India, for their valuable guidance, suggestions and help provided in the preparation of manuscript.

\section{Received: 10 June 2015 Accepted: 21 September 2015} Published online: 15 October 2015

\section{References}

1. Wilmut I, Schnieke AE, McWhir J, Kind AJ, Campbell KHS. Viable offspring derived from fetal and adult mammalian cells. Nature. 1997;385:810-3.

2. Willadsen SM. Nuclear transplantation in sheep embyos. Nature. 1986;320:63-5

3. Wakayama T, Pery AC, Zuccotti M, Johnson KR, Yanagimachi R. Full-term development of mice from enucleated oocytes injected with cumulus cell nuclei. Nature. 1998:394:369-74.

4. Vajta G, Lewis IM, Trounson AO, Purup S, Maddox-Hyttel P, Schmidt M, et al. Handmade somatic cell cloning in cattle: analysis of factors contributing to high efficiency in vitro. Biol Reprod. 2003;68:571-8.

5. Vajta G, Lewis IM, Hyttel P, Thouas GA, Trounson AO. Somatic cell cloning without micromanipulators. Cloning. 2001;3:89-95.

6. Booth PJ, Holm P, Callesen H. Application of the zona-free manipulation technique to porcine somatic cell nuclear transfer. Cloning Stem Cells. 2001:4:191-7.

7. Booth PJ, Tan BJ, Relpurth R, Holm P, Callesen H. Simplification of bovine somatic cell nuclear transfer by application of a zona-free manipulation technique. Cloning Stem cells. 2001;3:139-50.

8. Tatham BG, Dowsing AT, Trounson AO. Enucleation by centrifugation of in vitro-matured bovine oocytes for use in nuclear transfer. Biol Reprod. 1995:53:1088-94

9. Fulka J, Moor RM. Non invasive chemical enucleation of mouse oocytes. Mol Reprod Dev. 1993;34:427-30.

10. Khan FA, Bhat MH, Yaqoob SH, Waheed SM, Naykoo NA, Athar $\mathrm{H}$, et al In vitro development of goat-sheep and goat-goat zona-free cloned embryos in different culture media. Theriogenology. 2014;81:419-23.

11. Peura TT, Lewis IM, Trounson AO. The effect of recipient oocyte volume on nuclear transfer in cattle. Mol Reprod Dev. 1998;50:185-91.

12. Saini M, Selokar NL, Raja AK, Sahare AA, Singla SK, Chauhan MS, et al. Effect of donor cell type on developmental competence, quality, gene expression, and epigenetic status of interspecies cloned embryos produced using cells from wild buffalo and oocytes from domestic buffalo. Theriogenology. 2015;84:101-8

13. Campbell KH, Loi P, Otaegui PJ, Wilmut I. Cell cycle co-ordination in embryo cloning by nuclear transfer. Rev Reprod. 1996;1:40-6.

14. Gibbons J, Arat S, Rzucidlo J, Miyoshi K, Waltenburg R, Respess D, et al. Enhanced survivability of cloned calves derived from roscovitine-treated adult somatic cells. Biol Reprod. 2002;66:895-900.

15. Wells DN, Misica PM, Tervit HR. Production of cloned calves following nuclear transfer with cultured adult mural granulosa cells. Biol Reprod. 1999:60:996-1005.

16. Kubota C, Yamakuchi H, Todoroki J, Mizoshita K, Tabara N, Barber M, et al. Six cloned calves produced from adult fibroblast cells after long-term culture. Proc Natl Acad Sci U S A. 2000;97:990-5.
17. Kues WA, Anger M, Carnwath JW, Paul D, Motlik J, Niemann H. Cell cycle synchronization of porcine fetal fibroblasts: effects of serum deprivation and reversible cell cycle inhibitors. Biol Reprod. 2000;62:412-9.

18. Liu CT, Yu KC, Ju JC. Cell cycle stage analysis of rabbit foetal fibroblasts and cumulus cells. Reprod Domest Anim. 2004;39:385-90.

19. Campbell KHS, Fisher P, Chen WC, Choi I, Kelly RD, Lee JH, et al. Somatic cell nuclear transfer: Past, present and future perspectives. Theriogenology. 2007;68:214-31.

20. Sun $X$, Wang S, Zhang Y, Wang H, Wang L, Ying L, et al. Cell-cycle synchronization of fibroblasts derived from transgenic cloned cattle ear skin: effects of serum starvation, roscovitine and contact inhibition. Zygote. 2008;16:111-6.

21. Gerger RPC, Ribeiro ES, Forell F, Bertolini LR, Rodrigues JL, Ambrósio CE, et al. In vitro development of cloned bovine embryos produced by handmade cloning using somatic cells from distinct levels of cell culture confluence. Genet Mol Res. 2010;9:2953-02.

22. Pereira AF, Feltrin C, Almeida KC, Carneiro IS, Avelar SRG, Alcântara Neto AS, et al. Analysis of factors contributing to the efficiency of the in vitro production of transgenic goat embryos (Capra hircus) by handmade cloning (HMC). Small Rumin Res. 2013;109:163-72.

23. Vajta G, Holm P, Greve T, Callesen H. Overall efficiency of in vitro embryo production and vitrification in cattle. Theriogenology. 1996;45:683-9.

24. Holm P, Booth PJ, Schmidt MH, Greve T, Callesen H. High bovine blastocyst development in a static in vitro production system using SOFaa medium supplemented with sodium citrate and myo-inositol with or without serum proteins. Theriogenology. 1999;52:683-700.

25. Khatun M, Bhuiyan MMU, Ahmed JU, Haque A, Rahman MB, Shamsuddin M. In vitro maturation and fertilization of prepubertal and pubertal black Bengal goat oocytes. J Vet Sci. 2011;12:75-82.

26. Yuan Y, Krisher RL. In Vitro Maturation (IVM) of Porcine Oocytes. Wai-Yee Chan and Le Ann Blomberg (eds.), Germline Development: Methods and Protocols. Methods Mol Biol. 2012;825:183-98. doi:10.1007/978-1-61779-436-0_14.

27. Taylor-Robinson AW, Walton S, Swain DL, Walsh KB, Vajta G. The potential for modification in cloning and vitrification technology to enhance genetic progress in beef cattle in Northern Australia. Anim Reprod Sci. 2014;148:91-6.

28. Vajta G. Production of a healthy calf by somatic cell nuclear transfer without micromanipulators and carbon dioxide incubators using the Handmade Cloning (HMC) and the Submarine Incubation System (SIS). Theriogenology. 2004;62:1465-72

29. Elsheikh ASI. Handmade cloning of mammals. Afr J Biotechnol. 2007;6:1862-8.

30. Tani T, Shimada H, Kato Y, Tsunoda Y. Demecolcine-assisted enucleation for bovine cloning. Cloning Stem Cells. 2006;8:61-6.

31. Li S, Kang J-D, Jin J-X, Hong Y, Zhu H-Y, Jin L, et al. Effect of demecolcineassisted enucleation on the MPF level and cyclin B1 distribution in porcine oocytes. PLoS One. 2014;9(3):e9148. doi:10.1371/journal.pone.0091483.

32. Wu YG, Zhou P, Lan GC, Gao D, Li Q, et al. MPF governs the assembly and contraction of actomyosin rings by activating RhoA and MAPK during chemical-induced cytokinesis of goat oocytes. PLoS One. 2010;5:e12706.

33. Nagai T, Kikuchi K, Imai K, Fahrudin M. Handmade somatic cell cloning and related studies in farm animals. J Mamm Ova Res. 2007;24:99-106.

34. Iwamoto D, Yamagata K, Kishi M, Hayashi-Takanaka Y, Kimura H, Wakayama T, et al. Early development of cloned bovine embryos produced from oocytes enucleated by fluorescence metaphase II imaging using a conventional halogen-lamp microscope. Cell Reprogram. 2015;17:1061-14. doi:10.1089/ cell.2014.0086.

35. Vajta G, Peura TT, Holm P, Paldi A, Greve T, Trounson AO, et al. New method for culture of zona-included or zona-free embryos: the well of the well (WOW) system. Mol Reprod Dev. 2000;55:256-64.

36. Kaith S, Saini M, Raja AK, Sahare AA, Jyotsana B, Madheshiya P, et al. Early cleavage of handmade cloned buffalo (bubalus bubalis) embryos is an indicator of their developmental competence and quality. Reprod Domest Anim. 2015;50:214-20.

37. Vajta G, Holm P, Kuwayama M, Booth PJ, Jacobsen H, Greve T, et al. Open pulled straw (OPS) vitrification: a new way to reduce cryoinjuries of bovine ova and embryos. Mol Reprod Dev. 1998;51:53-8.

38. Tecirlioglu RT, French AJ, Lewis IM, Vajta G, Korfiatis NA, Hall VJ, et al. Birth of a cloned calf derived from a vitrified hand-made cloned embryo. Reprod Fertil Dev. 2003;15:361-6.

39. Vajta G, Rindom N, Peura TT, Holm P, Greve T, Callesen H. The effect of media, serum and temperature on in vitro survival of bovine blastocysts after open pulled straw (OPS) vitrification. Theriogenology. 1999;52:9399-48. 
40. Tecirlioglu RT, Cooney MA, Lewis IM, Korfiatis NA, Hodgson R, Ruddock NT, et al. Comparison of two approaches to nuclear transfer in the bovine: hand-made cloning with modifications and the conventional nuclear transfer technique. Reprod Fertil Dev. 2005;17:573-85.

41. Akshey YS, Malakar D, De AK, Jena MK, Sahu S, Dutta R. Study of the efficiency of chemically assisted enucleation method for handmade cloning in goat (Capra hircus). Reprod Domest Anim. 2011;46:699-704. doi:10.1111/j.1439-0531.2010.01732.x.

42. Wang HL, Chang ZL, Li KL, Lian HY, Han D, Cui W, et al. Caffeine can be used for oocyte enucleation. Cell Reprogram. 2011;13:225-32.

43. Li J, Villemoes K, Zhang Y, Du Y, Kragh PM, Purup S, et al. Efficiency of Two enucleation methods connected to handmade cloning to produce transgenic porcine embryos. Reprod Domest Anim. 2009;44:122-7. doi:10.1111/j.14390531.2007.01007.x.

44. Fischer-Russell D, Ibáñez E, Albertini DF, Overström EW. Activated bovine cytoplasts prepared by demecolcine-induced enucleation support development of nuclear transfer embryos in vitro. Mol Reprod Dev. 2005;72:161-70.

45. Ibáñez E, Albertini DF, Overström EW. Demecolcine-induced oocyte enucleation for somatic cell cloning: coordination between cell cycle egress, kinetics of cortical cytoskeletal interactions, and second polar body extrusion. Biol Reprod. 2003;68:1249-58.

46. Costa-Borges N, Paramio MT, Santalo J, Ibanez E. Demecolcine- and nocodazole-induced enucleation in mouse and goat oocytes for the preparation of recipient cytoplasts in somatic cell nuclear transfer procedures. Theriogenology. 2011;75:527-41.

47. Ribeiro Ede S, Gerger RP, Ohlweiler LU, Ortigari I, Mezzalira JC, Forell F, et al. Developmental potential of bovine hand-made clone embryos reconstructed by aggregation or fusion with distinct cytoplasmic volumes. Cloning Stem Cells. 2009;11:377-86.

48. Siriboon C, Tu CF, Kere M, Liu MS, Chang HJ, Ho LL, et al. Production of viable cloned miniature pigs by aggregation of handmade cloned embryos at the 4-cell stage. Reprod Fertil Dev. 2014;26:395-406. doi:10.1071/RD12243.

49. Boquest AC, Day BN, Prather RS. Flow cytometric cell cycle analysis of cultured porcine fetal fibroblast cells. Biol Reprod. 1999;60:1013-9.

50. Oback B, Wiersema AT, Gaynor P, Laible G, Tucker FC, Oliver JE, et al. Cloned cattle derived from a novel zona-free embryo reconstruction system. Cloning Stem Cells. 2003;5:3-12.

51. Jena MK, Malakar D, De AK, Garg S, Akshey YS, Dutta R, et al. Handmade cloned and parthenogenetic goat embryos- A comparison of different culture media and donor cells. Small Rumin Res. 2012;105:255-62.

52. Shah RA, George A, Singh MK, Kumar D, Chauhan MS, Manik R, et al. Hand-made cloned buffalo (Bubalus bubalis) embryos: comparison of different media and culture systems. Cloning Stem Cells. 2008;10:435-42.

53. Selokar NL, George A, Saha AP, Sharma R, Muzaffer M, Shah RA, et al. Production of interspecies handmade cloned embryos by nuclear transfer of cattle, goat and rat fibroblasts to buffalo (Bubalus bubalis) oocytes. Anim Reprod Sci. 2011;123:279-82.

54. Dutta R, Malakar D, Akshey YS, Sahu S, Jena MK, Banerjee D, et al. Production and characterization of putative ntES cells from handmade cloned goat embryos derived from adult fibroblast donor cells. J Reprod Stem Cell Biotechnol. 2011;2:64-76.

55. Akshey YS, Malakar D, De AK, Jena MK, Pawar SK, Dutta R, et al. Effect of roscovitine treated donor cells and different activation methods on development of handmade cloned goat (Capra hircus) embryos. Theriogenology. 2010;75:1516-24

56. Alberio R, Brero A, Motlik J, Cremer T, Wolf E, Zakhartchenko V. Remodeling of donor nuclei, DNA synthesis, and ploidy of bovine cumulus cell nuclear transfer embryos: effect of activation protocol. Mol Reprod Dev. 2001;59:371-9.

57. Kasinathan P, Knott JG, Moreira PN, Burnside AS, Jerry DJ, Robl JM. Effect of fibroblast donor cell age and cell cycle on development of bovine nuclear transfer embryos in vitro. Biol Reprod. 2001;64:1487-93.

58. Beyhan Z, Milatipova M, Chang TC, First N. Donor cell passage number, starvation period and fusion-activation interval affect preimplantation development of bovine nuclear transfer embryos. Theriogenology. 2002;57:396. abstract

59. Em S, Kataria MSB, Yadav P. Expression profile of developmentally important genes between hand-made cloned buffalo embryos produced from reprogramming of donor cell with oocytes extract and selection of recipient cytoplast through brilliant cresyl blue staining and in vitro fertilized embryos. J Assist Reprod Genet. 2014;31(11):1541-52. doi:10.1007/s10815-014-0316-y.

60. Mohapatra SK, Sandhu A, Neerukattu VS, Singh KP, Selokar NL, Singla SK et al. Buffalo embryos produced by handmade cloning from oocytes selected using brilliant cresyl blue staining have better developmental competence and quality and are closer to embryos produced by in vitro fertilization in terms of their epigenetic status and gene expression pattern. Cell Reprogram. 2015;17(2):141-50. doi:10.1089/cell.2014.0077.

61. Rodríguez-González E, López-Béjar M, Velilla E, Paramio MT. Selection of prepubertal goat oocytes using the brilliant cresyl blue test Theriogenology. 2002;57(5):1397-409.

62. Roca J, Martinez E, Vazquez JM, Lucas X. Selection of immature pig oocytes for homologous in vitro penetration assays with the brilliant cresyl blue test. Reprod Fertil Dev. 1998;10(6):479-86.

63. Vajta G, Kragh PM, Mango NR, Callesen H. Hand-made cloning approach: potentials and limitations. Reprod Fertil Dev. 2005;17:97-112.

64. Mahdi $\mathrm{E}$, Fakhrisadat $\mathrm{H}$. Handmade cloning: an alternative technique for somatic cell nuclear transfer. Annals of Biological Research. 2012;3:3043-8.

65. Elsheikh AS, Takahashi Y, Hishinuma M, Kanagawa H. Developmental ability of mouse late 2-cell stage blastomeres fused to chemically enucleated oocytes in vitro. J Vet Med Sci. 1997;59:107-13.

66. Suzuki H, Togashi M, Adachi J, Toyoda Y. Developmental ability of zona-free mouse embryos is influenced by cell association at the 4-cell stage. Biol Reprod. 1995;53:78-83.

67. Bronson RA, McLaren A. Transfer to the mouse oviduct of eggs with and without the zona pellucida. J Reprod Fertil. 1970;22:129-37.

68. O'Brien MJ, Critser ES, First NL. Developmental potential of isolated blastomeres from early murine embryos. Theriogenology. 1984;22:601-7.

69. Zhang P, Zhang Y, Dou H, Yin J, Chen Y, Pang X, et al. Handmade cloned transgenic piglets expressing the nematode fat-1 gene. Cell Reprogram. 2012;14:258-66.

70. Schmidt M, Kragh PM, Li J, Du Y, Lin L, Liu Y, et al. Pregnancies and piglets from large white sow recipients after two transfer methods of cloned and transgenic embryos of different pig breeds. Theriogenology. 2010;74:1233-40.

71. Lagutina I, Lazzari G, Duchi R, Turini P, Tessaro I, Brunetti D, et al. Comparative aspects of somatic cell nuclear transfer with conventional and zona-free method in cattle, horse, pig and sheep. Theriogenology. 2007:67:90-8.

72. Priya D, Selokar NL, Raja AK, Saini M, Sahare AA, Nala N, et al. Production of Wild Buffalo (Bubalus arnee) Embryos by Interspecies Somatic Cell Nuclear Transfer Using Domestic Buffalo (Bubalus bubalis) Oocytes. Reprod. Dom. Anim. 2014;1-9. doi: 10.1111/rda.12284.

73. Zhang P, Liu P, Dou H, Chen L, Chen L, Lin L, et al. Handmade cloned transgenic sheep rich in omega-3 fatty acids. PLoS ONE. 2013;8(2):e55941. doi:10.1371/journal.pone.0055941.

74. Vajta G. Handmade cloning: the future way of nuclear transfer? Trends Biotechnol. 2007;25(6):250-3.

75. Constant F, Guillomot M, Heyman Y, Vignon X, Laigre P, Servely $J$, et al. Large offspring or large placenta syndrome? morphometric analysis of late gestation bovine placentomes from somatic nuclear transfer pregnancies complicated by hydrallantois. Biol Reprod. 2006;75:122-30.

76. Farin PW, Piedrahita JA, Farin CE. Errors in development of fetuses and placentas from in vitro-produced bovine embryos. Theriogenology. 2006;65:178-91.

77. Bertolini M, Bertolini LR, Gerger RPC, Batchelder CA, Anderson GB. Developmental problems during pregnancy after in vitro embryo manipulations. Rev Bras Reprod Anim. 2007;31:391-405.

78. Cibelli JB, Stice SL, Golueke PJ, Kane JJ, Jerry J, Blackwell C, et al. Cloned transgenic calves produced from nonquiescent fetal fibroblasts. Science. 1998;280:1256-8

79. Kato Y, Tani T, Sotomaru Y, Kurokawa K, Kato J, Doguchi H, et al. Eight calves cloned from somatic cells of a single adult. Science. 1998;282:2095-8.

80. Bartels P, Joubert J, de la Rey M, de la Rey R, Treadwell R, Callesen H, et al. 27 Birth of Africa's first nuclear-transferred animal produced with handmade cloning. Reprod Fertil Dev. 2003;16(2):136. http://dx.doi.org/10.1071/ RDv16n1Ab27.

81. Hall VJ, Ruddock NT, Cooney MA, Korfiatis NA, Tecirlioglu RT, Downie S, et al. Production of a cloned calf using zona-free serial nuclear transfer. Theriogenology. 2006;65:424-40. 
82. Shi D, Lu F, Wei Y, Cui K, Yang S, Wei J, et al. Buffalos (Bubalus bubalis) cloned by nuclear transfer of somatic cells. Biol Reprod. 2007;77:285-91.

83. George A, Sharma R, Singh KP, Panda SK, Singla SK, Palta P, et al. Production of cloned and transgenic embryos using buffalo (Bubalus bubalis) embryonic stem cell-like cells isolated from in vitro fertilized and cloned blastocysts. Cell Reprogr. 2011;13:263-72.

84. Baguisi A, Behboodi E, Melican DT, Pollock JS, Destrempes MM, Cammuso C. Production of goats by somatic cell nuclear transfer. Nat Biotechnol. 1999;17(5):456-61.

85. Reggio BC, James AN, Green HL, Gavin WG, Behboodi E, Echelard Y, et al. Cloned transgenic offspring resulting from somatic cell nuclear transfer in the goat: oocytes derived from both follicle stimulating hormone-stimulated and non stimulated abattoir-derived ovaries. Biol Reprod. 2001;65:1528-33.

86. Keefer CL, Keyston R, Lazaris A, Bhatia B, Begin I, Bilodeau AS, et al. Production of cloned goats after nuclear transfer using adult somatic cells. Biol Reprod. 2002;66:199-203.

87. Lan GC, Chang ZL, Luo MJ, Jiang YL, Han D, Wu YG. Production of cloned goats by nuclear transfer of cumulus cells and long-term cultured fetal fibroblast cells into abattoir-derived oocytes. Mol Reprod Dev. 2006;73:834-40.

88. Polejaeva IA, Chen SH, Vaught TD, Page RL, Mullins J, Ball S, et al. Cloned pigs produced by nuclear transfer from adult somatic cells. Nature. 2000;407:86-90.

89. Du Y, Kragh PM, Zhang Y, Li J, Schmidt M, Bogh IB, et al. Piglets born from handmade cloning, an innovative cloning method without micromanipulation. Theriogenology. 2007;68:1104-10.

90. Lagutina I, Lazzari G, Galli C. Birth of cloned pigs from zona-free nuclear transfer blastocysts developed in vitro before transfer. Cloning Stem Cells. 2006;8:283-93.

91. Galli C, Lagutina I, Crotti G, Colleoni S, Turini P, Ponderato N, et al. Pregnancy: a cloned horse born to its dam twin. Nature. 2003;424:635.

92. Lagutina I, Lazzari G, Duchi R, Colleoni S, Ponderato N, Turini P, et al. Somatic cell nuclear transfer in horses: effect of oocyte morphology, embryo reconstruction method and donor cell type. Reproduction. 2005;130:559-67.

93. Shin T, Kraemer D, Pryor J, Liu L, Rugila J, Howe L, et al. A cat cloned by nuclear transplantation. Nature. 2002;415:859.

94. Chesne P, Adenot PG, Viglietta C, Baratte M, Boulanger L, Renard JP. Cloned rabbits produced by nuclear transfer from adult somatic cells. Nat Bio-technol. 2002;20:366-9.

95. Zhou Q, Renard JP, Le Friec G, Brochard V, Beaujean N, Cherifi Y, et al. Generation of fertile cloned rats by regulating oocyte activation. Science. 2003:302:1179

96. Lee BC, Kim MK, Jang G, Oh HJ, Yuda F, Kim HJ, et al. Dogs cloned from adult somatic cells. Nature. 2005;436:641.

97. Li Z, Sun X, Chen J, Liu X, Wisely SM, Zhou Q, et al. Cloned ferrets produced by somatic cell nuclear transfer. Dev Biol. 2006;293(2):439-48.

98. Kim MK, Jang G, Oh HJ, Yuda F, Kim HJ, Hwang WS, et al. Endangered wolves cloned from adult somatic cells. Cloning Stem Cells. 2007:9(1):130-7.

99. Woods GL, White KL, Vanderwall DK, Li GP, Aston Kl, Bunch TD, et al. A mule cloned from fetal cells by nuclear transfer. Science. 2003;301:1063.

100. Wani NA, Wernery U, Hassan FA, Wernery R, Skidmore JA. Production of the first cloned camel by somatic cell nuclear transfer. Biol Reprod. 2010;82:373-9.

101. Elsheikh AS, Kanagawa H. Improvement of mouse egg microdisection. Sudan J Basic Sci (B). 2003:8:55-69.

102. Elsheikh AS, Takahashi Y, Katagiri S, Kanagawa H. Sucrose exposed chemically enucleated mouse oocytes support blastocyst development of reconstituted embryos. Reprod Fertil Dev. 2006;18:697-701.

103. Bhojwani S, Vajta G, Callesen H, Roschlau K, Kuwer A, Becker F, et al. Developmental competence of HMC (TM) derived bovine cloned embryos obtained from somatic cell nuclear transfer of adult fibroblasts and granulosa cells. J Reprod Dev. 2005;51:465-75.

104. Inoue K, Wakao H, Ogonuki N, Miki H, Seino K, Nambu-Wakao R, et al. Generation of cloned mice by direct nuclear transfer from natural killer $T$ cells. Curr Biol. 2005;15:1114-8.

105. Akshey YS, Malakar D, De AK. Production of handmade cloned goat blastocysts using fetal fibroblast cells. Reprod Fertil Dev. 2008;20:91-2.
106. Meena CR, Das SK. Development of water buffalo (Bubalus bubalis) embryos from in vitro matured oocytes reconstructed with fetal skin fibroblast cells as donor nuclei. Anim Reprod Sci. 2006;93:258-67.

107. Malik HN, Dubey AK, Singhal DK, Saugandhika S, Mohapatra SK, Malakar D. Generation of handmade cloned embryos from adipose tissue derived mesenchymal stem cells in goat. Small Ruminant Res. 2014; http://dx.doi.org/10.1016/j.smallrumres.2014.09.004

\section{Submit your next manuscript to BioMed Central and take full advantage of:}

- Convenient online submission

- Thorough peer review

- No space constraints or color figure charges

- Immediate publication on acceptance

- Inclusion in PubMed, CAS, Scopus and Google Scholar

- Research which is freely available for redistribution

Submit your manuscript at www.biomedcentral.com/submit
C Biomed Central 